\title{
Pharmacoeconomic Aspects of Low Back Pain Treatment: Cost of Illness Study in the Republic of Serbia
}

\author{
Aspetos Farmaco-Económicos no Tratamento da Dor \\ Lombar: Estudo do Custo da Doença na República da \\ Sérvia
}

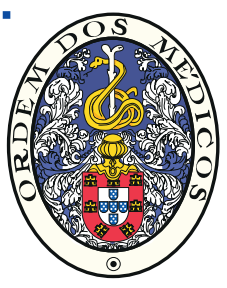

Matija J. RADOIČIĆ ${ }^{1}$, Bojana V. BOŽOVIĆ ${ }^{1}$, Katarina D. Parezanović ILIĆ Jelena Z. ANĐELKOVIĆ ${ }^{5}$, Marina J. KOSTIĆ $\square^{4}$

Acta Med Port 2019 Apr;32(4):272-278 - https://doi.org/10.20344/amp.10910

\section{ABSTRACT}

Introduction: Chronic diseases with disabilities have a huge pharmacoeconomic impact on the health budget, especially in countries with recent history of social and economic transition. The aim of this study was to identify total costs of treating patients with lumbar pain in medical facilities in the central part of the Republic of Serbia.

Material and Methods: This study was designed as a cost of illness study, using a bottom-up approach and it was conducted from a societal perspective. This study included 97 patients with lumbar syndrome who were treated in outpatient facilities in the Central part of Serbia.

Results: Total costs of treating lumbar pain were about $€ 200.40 \pm € 86.65$ per patient per year, where the largest volume of direct costs were costs due to visits to specialists in primary health care institutions (€9.39 $\pm € 6$.66). Total indirect costs were $€ 182.00 \pm € 78.66$.

Discussion: Our findings highlight the need to estimate the total costs of treating lumbar pain and evaluate the correlation between costs and other variables for larger population of these patients.

Conclusion: This study distinguished two important pharmacoeconomic aspects of treating lumbar pain. Firstly, indirect costs represent major part of total costs of treating lumbar syndrome. Secondly, differences in valuing medical services between countries with recent history of social and economic transition and countries within European Union are one of crucial reasons for difference in total costs of treating low back pain among patients in neighboring regions.

Keywords: Cost-Benefit Analysis; Economics, Pharmaceutical; Low Back Pain/drug therapy; Low Back Pain/economics; Republic of Serbia

\section{RESUMO}

Introdução: As doenças crónicas incapacitantes têm um grande impacto fármaco-económico no orçamento da saúde, especialmente em países com alterações recentes a nível dos aspetos sociais e económicos. O objetivo deste estudo foi avaliar os custos do tratamento da dor lombar em unidades de saúde na região central da República da Sérvia.

Material e Métodos: Este estudo foi realizado de forma a avaliar os custos da doença, com uma abordagem de baixo para cima e conduzido a partir de uma perspetiva social. O estudo incluiu 97 doentes com síndrome lombar tratados em ambulatório na região central da Sérvia.

Resultados: $O$ custo total do tratamento da dor lombar foi de $€ 200.40 \pm € 86.65$ por doente por ano, tendo os custos diretos de maior volume associados às consultas de especialidade em unidades de saúde de cuidados primários sido de $€ 9,39 \pm € 6,66$. O custo total indireto foi de $€ 182,00 \pm € 78,66$.

Discussão: Do nosso estudo destaca-se a necessidade de estimar os custos totais do tratamento da dor lombar e de avaliar a correlação entre os custos e outras variáveis para maiores grupos de doentes.

Conclusão: Este estudo faz a distinção entre dois importantes aspetos farmacoeconómicos no tratamento da dor lombar. Primeiro, os custos indiretos representam a maior parte dos custos totais no tratamento da síndrome lombar. Em segundo lugar, as diferenças na avaliação realizada nas unidades de saúde entre os países com alterações recente a nível dos aspetos sociais e económicos e os países da União Europeia são uma das principais razões para a diferença nos custos totais do tratamento da lombalgia entre doentes de regiões próximas.

Palavras-chave: Análise Custo-Benefício; Dor Lombar/economia; Dor Lombar/tratamento; Farmacoeconomia; República da Sérvia

\section{INTRODUCTION}

Lumbar syndrome is a set of symptoms and signs characterized by acute pain or chronic pain in the lumbosacral region of the spinal column, with the occurrence of paravertebral muscular spasm, which arises as a result of a protective muscular reaction to low back pain, and often the symptoms of compressive radiculopathy are present. ${ }^{1,2}$
Lumbar syndrome is important because of its high frequency, especially in Western countries, and its relapsing property, which gives this health problem a social and economic significance. ${ }^{3-5}$ The prevalence of low back pain has an increasing tendency, especially among female patients and patients aged $40-80$ years. The highest incidence of

1. Department of Pharmacy. Faculty of Medical Sciences. University of Kragujevac. Kragujevac. Serbia

2. Department of Physical Medicine and Rehabilitation. Faculty of Medical Sciences. University of Kragujevac. Kragujevac. Serbia.

3. Department of Pharmacology and Toxicology. Clinical Centre Kragujevac. Kragujevac. Serbia.

4. Department of Pharmacology and Toxicology. Faculty of Medical Sciences. University of Kragujevac. Kragujevac. Serbia.

5. Medicines and Medical Devices Agency of Serbia. Kragujevac. Serbia

$\bowtie$ Autor correspondente: Marina Kostić. marrina2006kg@yahoo.com

Recebido: 05 de junho de 2018 - Aceite: 26 de setembro de 2018 | Copyright @ Ordem dos Médicos 2019 
low back pain is in the third decade of life, which is important from social and economic aspect of treating this condition since this medical condition reduces the productivity of patients at work. It is estimated that approximately $9.2 \%$ of world population suffers from symptoms of low back pain and that $75 \%$ of population of developed countries is endangered by this medical condition. ${ }^{6}$ The one year prevalence varies from $9.7 \%$ in Finland to $50.3 \%$ in Ukraine. The recurrence of low back pain is estimated to be between $24 \%$ and $80 \%$ at one year. ${ }^{7}$ The data on prevalence in the Balkan region are not available in published literature.

Namely, all patients in the acute phase of the lumbar syndrome are temporarily unable to working. Even if temporary, disability can limit the ability to work, to a greater or lesser extent; in particular, there is an increase in the number of sick leave days and absence from the workplace due to lumbar problems. ${ }^{8}$ The largest number of temporarily incapacitated persons is in a productive part of the population (40 - 50 years old), which makes this health problem even more challenging. ${ }^{9}$ The pharmacoeconomic aspects of treating chronic medical conditions are a challenge not only for countries with a stable economy, but also for countries with a recent history of social and economic transition like the countries in the Balkan region. These medical conditions positively correlate with disability, productivity loss and disability retirement since the domain of these indirect costs frequently overcomes the value of direct costs. ${ }^{10}$

In most cases, the management of lumbar syndrome and low back pain should start in primary care. There are two ways of treating lumbar syndrome, namely conservative and operative treatment. Within the framework of conservative treatment, the following modalities and techniques are applied: 1. medicinal therapy (analgesics, NSAIDs, corticosteroids, muscle relaxants, antiepileptics, tricyclic antidepressants); 2. therapeutic lifestyle; 3. physical therapy (TENS, traction, therapeutic exercises, laser-, magneto-, hydro-, thermo-, electro- and sonotherapy, massage, acupuncture, spinal axial decompression); 4. osteopathic therapy and chiropractics; 5 . cognitive behavioral therapy. ${ }^{11-14}$ Treating medical conditions accompanied with acute and chronic low back pain, like lumbar syndrome, has a multidimensional aspect since it includes various individual, physical, psychosocial and work-related etiological factors. ${ }^{11}$ All these etiological factors contribute to the growth of the societal burden of this disease, which makes lumbar syndrome important topic in pharmacoeconomic research, especially in the domain of cost of illness study.

The main aim of a cost of illness study is to capture and value all types of direct, indirect and intangible costs of specific disease. Results of cost of illness studies are important for decision making in a health care system, since they provide data on the volume of use of different structures of health care providers and organizations. ${ }^{15}$ The final result of a cost of illness study can be a useful tool for decision makers in health care systems to determine which diseases have higher priority in terms of health care and prevention strategies. Additionally, a cost of illness study is a feasible technique that can be a part of other pharmacoeconomic studies, such as cost-effectiveness and cost-benefit analyses. ${ }^{16}$ Finally, the result of this type of pharmacoeconomic study can provide a solution for a framework of economic program evaluation within health care systems, which is very important in systems with limited economic resources.

Despite the fact that the economic aspects of treating lumbar pain have been identified in recent pharmacoeconomic literature, the economic burden of lumbar pain in the Balkan countries with a recent history of social and economic transition is mainly unknown. This can be explained by the lack of a comprehensive patient register and by the fact that certain procedures used in treating lumbar syndrome are mostly carried out in private medical facilities. ${ }^{15}$

The aims of this study were: to define the profile and structure of costs derived from patients treated for lumbar pain in central part of the Republic of Serbia; II) to determine the utilization of resources among patients with lumbar pain in central part of the Republic of Serbia; and to estimate variables that mostly affect total costs of treating lumbar pain.

\section{MATERIAL AND METHODS \\ Study design}

In order to evaluate the total outpatient costs of lumbar syndrome, we designed a pilot pharmacoeconomic cost of illness study, with a bottom-up approach. Firstly, we estimated the quantity of health services and then unit costs of these services, while total costs were calculated by multiplying unit costs with quantities. We collected data by interviewing patients and by analyzing medical records of patients, which provide a more realistic insight into medical care utilization in comparison to national surveys. Using a bottom-up approach we minimized misallocation of costs as under- or overestimated total direct costs, exclusion of cost categories that are not included in national health care expenditures, which is usually seen when a top-down approach is used. ${ }^{16}$

This study was retrospective and it was conducted from a societal perspective. This study was approved by the Ethics Committee of Primary Health Institution in Kragujevac (Authorization No. 01 - 5099/3).

\section{Patient selection}

To estimate the sample size, we used the formula for cost of illness study: $n=(1.96)^{2} \times 4^{*} S^{2} / d^{2}$, where $S D$ is standard deviation of measured costs and $d$ is width of the confidence interval. ${ }^{17}$ According to available data from the published pharmacoeconomic literature (standard deviation of 58237 Norwegian kroner, and confidence interval of $2 * 1.96 * \mathrm{SE}=2 * 1.96^{*} 58237$ Norwegian kroner/sqr (87) $=2 * 1.96 * 58$ 237/9,3 = 24 547,2 Norwegian kroner), we calculated the total size of population of 86 patients and added $10 \%$ to the estimated sample size. ${ }^{18}$ Firstly, we identified all medical documents signed with diagnosis of lumbar pain (M54 - low back pain) and then we enrolled only patients who voluntary consented to complete a 
questionnaire. The questionnaire was constructed on the basis of the available literature on lumbar pain, and included items about demographic, clinical and pharmacoeconomic data. Demographic data included general information on patients (patient's age, sex, occupation) while clinical data involved information about disease (duration of disease, cause). In order to obtain data on the pharmacoeconomic aspects of treating lumbar pain, we enrolled 97 patients who were treated in the primary healthcare institution in Kragujevac, in Central Serbia for this medical condition from April 2016 to April 2017.

\section{Inclusion criteria}

All patients should have been diagnosed as M54, which refers to lumbar pain (Dorsalgia) in one of the facilities of Primary Healthcare Institution of Kragujevac, in the central part of Serbia from April 2016 to April 2017 and their medical documentation had to be properly filled.

\section{Data collection}

The data were collected from the patient files by all six investigators and entered into an Excel spreadsheet. Data about outpatient direct costs included: number and type of visits to general practice and specialists, number of laboratory blood tests during last year, number of visits to physicians due to lumbar pain during last year, number of radiological examinations during last year, the data about pharmacotherapy and the data about rehabilitation treatments during last year. Pharmacotherapy of lumbar pain included different classes of non steroidal anti-inflammatory drugs, analgesics, muscle relaxants, as well as medicinal products for treating or preventing adverse drug reactions to this pharmacotherapy, which can also be used in treating other medical conditions. In order to evaluate the pharmacotherapy costs of lumbar pain, we only included medicinal products that were administered for the reason of lumbar pain, according to the completed questionnaire and available medical records. Information on home visits, home care, transport of the patients and disability-related financial support received from National Health Insurance Fund (NHIF) were also included. ${ }^{19}$

Indirect and out-of-pocket costs were estimated on the basis of data on lost wages of patients and their caregivers, costs for additional medical care, costs of transport to-andfrom health care facilities, costs of rehabilitation in health resorts. We also included questions on costs due to physical

Table 1 - Clinical characteristics of patients and average and total direct costs of lumbar pain per patient with lumbar pain

\begin{tabular}{|c|c|c|c|c|c|c|}
\hline Variable & $\begin{array}{l}\text { Median } \\
\text { (range) }\end{array}$ & $\begin{array}{c}\text { Unit } \\
\text { costs }^{19}\end{array}$ & $\begin{array}{l}\text { Average costs } \\
\text { per patient } \\
\text { (RSD) }\end{array}$ & $\begin{array}{c}\text { Average costs } \\
\text { per patient } \\
(€)\end{array}$ & $\begin{array}{l}\text { Total costs } \\
\text { (RSD) }\end{array}$ & $\begin{array}{l}\text { Total costs } \\
\text { (EUR) }\end{array}$ \\
\hline $\begin{array}{l}\% \text { male / } \\
\text { female }\end{array}$ & 42.26 / 57.73 & N.A. & N.A. & N.A. & N.A. & N.A. \\
\hline Age & $\begin{array}{c}53.59 \\
(28-85)\end{array}$ & N.A. & N.A. & N.A. & N.A. & N.A. \\
\hline $\begin{array}{l}\text { Duration } \\
\text { of disease } \\
\text { (months) }\end{array}$ & $\begin{array}{c}66.61 \\
(4-228)\end{array}$ & N.A. & N.A. & N.A. & N.A. & N.A. \\
\hline $\begin{array}{l}\text { Number } \\
\text { of visits } \\
\text { to general } \\
\text { practitioner }\end{array}$ & $\begin{array}{c}4.38 \\
(1-22)\end{array}$ & $356 ., 44$ & $\begin{array}{c}1156.93 \pm 820.34 \\
1037.96 \\
(259.49-5708.78)\end{array}$ & $\begin{array}{c}9.42 \pm 6.68 \\
8.48 \\
(2.11-46.51)\end{array}$ & $\begin{array}{c}7128.8 \pm 727.14 \\
0 \\
(259.49-5,08.78)\end{array}$ & $\begin{array}{c}58.08 \pm 5.92 \\
0 \\
(2.11-46.51)\end{array}$ \\
\hline $\begin{array}{l}\text { Number of } \\
\text { visits to } \\
\text { neurologist }\end{array}$ & $\begin{array}{c}0.11 \\
(0-2)\end{array}$ & 384.45 & $\begin{array}{c}79.27 \pm 229.43 \\
0 \\
(0-1537.80)\end{array}$ & $\begin{array}{c}0.64 \pm 1.87 \\
0 \\
(0-12.53)\end{array}$ & $\begin{array}{c}7689 \pm 228.38 \\
0 \\
(0-1537.8)\end{array}$ & $\begin{array}{c}62.65 \pm 1.86 \\
0 \\
(0-12.53)\end{array}$ \\
\hline $\begin{array}{l}\text { Number of } \\
\text { visits to } \\
\text { physiatrist }\end{array}$ & $\begin{array}{c}0.21 \\
(0-4)\end{array}$ & 404.96 & $\begin{array}{c}45.92 \pm 142.35 \\
0 \\
(0-809.92)\end{array}$ & $\begin{array}{c}0.37 \pm 1.160 \\
0 \\
(0-6.60)\end{array}$ & $\begin{array}{c}4454.56 \pm 141.70 \\
0 \\
(0-809.2)\end{array}$ & $\begin{array}{c}36.29 \pm 1.15 \\
0 \\
(0-6.59)\end{array}$ \\
\hline $\begin{array}{l}\text { Complete } \\
\text { blood } \\
\text { count }\end{array}$ & $\begin{array}{c}0.14 \\
(0-2)\end{array}$ & 353.00 & $\begin{array}{c}7.06 \pm 18.21 \\
0 \\
(0-85.64)\end{array}$ & $\begin{array}{c}0.06 \pm 0.05 \\
0 \\
(0-0.70)\end{array}$ & $\begin{array}{c}685.12 \pm 70.13 \\
0 \\
(0-85.64)\end{array}$ & $\begin{array}{c}5.58 \pm 0.57 \\
0 \\
(0-0.69)\end{array}$ \\
\hline $\begin{array}{l}\text { Electro- } \\
\text { miography }\end{array}$ & $\begin{array}{c}0.01 \\
(0-1)\end{array}$ & 668.61 & $\begin{array}{c}6.90 \pm 67.89 \\
0 \\
(0-668.61)\end{array}$ & $\begin{array}{c}0.06 \pm 0.55 \\
0 \\
(0-5.45)\end{array}$ & $\begin{array}{c}668.61 \pm 67.89 \\
0 \\
(0-668.61)\end{array}$ & $\begin{array}{c}5.44 \pm 0.55 \\
0 \\
(0-5.44)\end{array}$ \\
\hline Spine MRI & $\begin{array}{c}0.09 \\
(0-2)\end{array}$ & 2552.38 & $\begin{array}{c}236.82 \pm 908.58 \\
0 \\
(0-5104.76)\end{array}$ & $\begin{array}{c}1.93 \pm 7.40 \\
0 \\
(0-41.59)\end{array}$ & $\begin{array}{c}22971.42 \pm 908.58 \\
0 \\
(0-5104.76)\end{array}$ & $\begin{array}{c}187.17 \pm 7.40 \\
0 \\
(0-41.59)\end{array}$ \\
\hline
\end{tabular}


rehabilitation, alternative and complementary therapies, as well as over-the-counter medicinal products. For estimating productivity losses, we used a human capital approach. Productivity losses were involved in questionnaire in order to identify occurrence of temporary absence of patients due to lumbar pain, reduced number of working days due to lumbar pain or permanent work disability.

In order to estimate the outpatient costs of lumbar pain, we used the official tariff book of the National Health Insurance Fund, and to capture the costs of medical services we used prices from the Official Gazette of the Republic of Serbia. ${ }^{19-21}$ For the purpose of this survey, we collected all the costs in Serbian Dinars (RSD) and then converted them to Euros $(E €)$ using the exchange rate of National Bank of Serbia of 19 May 2017. (1 EUR = 122.73 RSD)

\section{Statistical analysis}

All data derived from patients and from medical documentations were collected and incorporated into an Excel spreadsheet. All results were expressed as mean $\pm 95 \%$ confidence interval, standard deviation, median and range. We used Spearman's coefficient to evaluate the strength of correlation between independent or confounding with dependent variables.

\section{RESULTS}

There were 97 participants in our study, 56 women and 41 men with a median age of 55 (range 28 to 85 years). The median duration of pain was 66.61 months (range $4-228$ ).

Clinical characteristics of patients, the level of utilization of medical services as a value of these services translated into direct costs are presented in Table 1.

The total costs of treating lumbar pain for all patients in our study were estimated to be $2385668.56 \pm 241237.85$ Serbian dinars or $€ 19438.34 \pm € 1965.59$ while the total costs of treating lumbar pain per patient were estimated to be $24594.52 \pm 36400.05$ Serbian Dinars or $€ 200.40 \pm$ $€ 296.59$.

The core costs of pharmacotherapy per patient, which are estimated to be $724.23 \pm 637.89$ Serbian dinars or $€ 5.90 \pm € 5.19$, are represented by anti-inflammatory and anti-rheumatic products (34.19\%), by tolperisone $(21.05 \%)$, corticosteroids $(13.7 \%)$, vitamins $(10.6 \%)$, benzodiazepine derivates $(7.75 \%)$ and mannitol $(2.33 \%)$.

The structure and values of indirect costs are presented in Table 2 and average total costs are summarized and presented in Table 3.

The values of average costs of treating lumbar pain in relation to gender are presented in Table 4.

\section{DISCUSSION}

Taking into consideration the high prevalence of lumbar syndrome and its significant impact on reduced work ability, it is important to capture pharmacoeconomic aspects of treating patients with low back pain. Our survey was cost of illness study with a bottom-up approach that was performed from a societal perspective. This kind of perspective is especially important for diseases like lumbar syndrome, since costs are generated due to productivity losses. In our study, total cost of lumbar pain per patient per year in the central part of Serbia is estimated to be $€ 199.67 \pm € 295.52$, which represents $1.65 \%$ of gross domestic product (adjusted per purchasing power parity) (GDP per capita PPP). ${ }^{22}$ In Switzerland, total cost of lumbar pain is estimated to be $1.7 \%$ of GDP per capita PPP, which is similar to our results. ${ }^{22,23}$ The main result of our study is that total outpatient costs per

Table 2 - Indirect costs of lumbar pain per patient

\begin{tabular}{|c|c|c|}
\hline Variable & $\begin{array}{l}\text { Costs } \\
\text { (RSD) }\end{array}$ & $\begin{array}{c}\text { Costs } \\
(€)\end{array}$ \\
\hline $\begin{array}{l}\text { Visits to general practitioners, neurologists and physiatrists } \\
\text { (including diagnostic procedures) }\end{array}$ & $\begin{array}{c}7114.43 \pm 7327.42 \\
5000.00 \\
(0-30400.00)\end{array}$ & $\begin{array}{c}57.97 \pm 59.70 \\
40.73 \\
(0-247.70)\end{array}$ \\
\hline Pharmacotherapy and orthopedic aids & $\begin{array}{c}1632.64 \pm 1595.49 \\
1242.06 \\
(0-8282.80)\end{array}$ & $\begin{array}{c}13.30 \pm 13.00 \\
10.12 \\
(0-67.49)\end{array}$ \\
\hline Productivity losses & $\begin{array}{c}12155.64 \pm 31485.81 \\
0 \\
(0-151360.60)\end{array}$ & $\begin{array}{c}99.04 \pm 256.54 \\
0 \\
(0-1233.28)\end{array}$ \\
\hline Transport to-and-from health care facilities & $\begin{array}{c}394.74 \pm 505.99 \\
240.00 \\
(0-2310.00)\end{array}$ & $\begin{array}{c}3.23 \pm 4.12 \\
1.95 \\
(0-18.82)\end{array}$ \\
\hline Rehabilitation in health resorts & $\begin{array}{c}1029.38 \pm 2700.04 \\
0 \\
(0-16050.00)\end{array}$ & $\begin{array}{c}8.38 \pm 21.99 \\
0 \\
(0-130.77)\end{array}$ \\
\hline
\end{tabular}

All costs are presented as 'mean $\pm \mathrm{SD}$, median and range' 
Table 3 - Average total outpatient costs of lumbar syndrome per patient

\begin{tabular}{lcc}
\hline Variable & $\begin{array}{c}\text { Costs } \\
\text { (RSD) }\end{array}$ & $\begin{array}{c}\text { Costs } \\
\text { (EUR) }\end{array}$ \\
\hline Average total direct costs & $2257.12 \pm 1653.5$ & $18.39 \pm 13.32$ \\
& $(585427.31-589941.55)$ & $(11.71-57.39)$ \\
Average total indirect costs & $22337.40 \pm 9654.00$ & $182.00 \pm 78.66$ \\
& $(13358198.36-13380535.76)$ & $(1049.20-1413.00)$ \\
Average total costs & $24594.52 \pm 10633.96$ & $(17503.82 \pm 86.65$ \\
\end{tabular}

All costs are presented as 'mean $\pm \mathrm{SD}$, median and range'

patient with lumbar pain per year in the pharmacoeconomic milieu of Serbia, which are estimated to be approximately $€ 199$, are lower than in Sweden (€632) or in Japan (3 300 196 Yen or $€ 22$ 754.22 Euros). ${ }^{24,25}$ These differences should be evaluated taking into consideration the social and economic status of the examined population, since prices of medical services in the Republic of Serbia are significantly lower than in other European developed countries, while prices of medicinal products are similar. For example, the prices of visits to the general practitioner are six fold higher in United Kingdom than in Republic of Serbia, while the price of one hospital day in the Republic of Serbia is approximately $€ 10$ to $€ 20 .{ }^{25}$ This difference in valuing medical services between countries with recent history of social and economic transition and European Union member states is one of the crucial reasons for the difference in total costs of treating low back pain among patients in neighboring countries. ${ }^{10}$ Furthermore, differences can be observed in terms of direct costs. Direct costs of treating low back pain in our survey were estimated to be $€ 18$, while the value of this part of total costs in Sweden is $€ 105$. These differences can be explained by the fact that costs of hospitalizations were not part of the captured total costs of treating low back pain in our study, since patients in our survey did not use those medical facilities. Similar findings were presented in study of Carregaro LR et al, who pointed that direct cost of spinal disorders encompassed larger volume of total costs in economic sphere of Brazil, but in these studies costs of inpatient care were dominant. ${ }^{26}$ This differences can be explained by the fact that costs of hospitalizations were not part of captured total costs of treating low back pain in our study, since patients in our survey did not use those medical facilities.

The main structural part of total direct costs were costs of treating low back pain in primary health care institutions $(51 \%)$, which indicates that patients with lumbar pain in the pharmacoeconomic sphere of the Republic of Serbia mostly use outpatient medical services. A significant correlation was found only between total cost and number of visits to the general practitioner (Spearman's coefficient was 0.9418, $p \leq 0.001$ ) and between total costs and number of visits to other specialists (Spearman's coefficient was 0.9289; $p \leq$ 0.001 ), indicating that if patients seek medical assistance due to lumbar pain a greater volume of total costs would be generated more frequently.

Regarding gender, we could observe slight differences among all types of costs between women and men. This could be explained by the fact that women, due to loss of elasticity of the muscles in the pelvic floor or the lower arch of the abdominal cavity induced by pregnancy and delivery, are more commonly affected by changes in kinesiological relations of the spine and by the onset of back pain, which induce increase of costs of treating lumbar pain in comparison to men. ${ }^{27}$

The important part of the total costs of treating lumbar pain were costs of medicinal products, which are presented as a part of direct costs $(32.1 \%)$ and also as a part of indirect costs $(6.74 \%)$. It is not a surprise that anti-inflammatory and anti-rheumatic products, muscle relaxants and corticosteroids are the main determinants of the total costs of pharmacotherapy in our study since these medicinal products are the core therapy for lumbar syndrome in global

Table 4 - Average direct, indirect and total costs of treating lumbar pain in relation to gender

\begin{tabular}{|c|c|c|c|c|c|c|}
\hline $\begin{array}{l}\text { Genderl } \\
\text { Variable }\end{array}$ & $\begin{array}{l}\text { Average direct } \\
\text { costs } \\
\text { (RSD) }\end{array}$ & $\begin{array}{l}\text { Average indirect } \\
\text { costs } \\
\text { (RSD) }\end{array}$ & $\begin{array}{l}\text { Total costs } \\
\text { (RSD) }\end{array}$ & $\begin{array}{c}\text { Average } \\
\text { direct costs } \\
(€)\end{array}$ & $\begin{array}{c}\text { Average } \\
\text { indirect costs } \\
(€)\end{array}$ & $\begin{array}{l}\text { Total costs } \\
(€)\end{array}$ \\
\hline Women & $\begin{array}{c}2360.21 \pm 1710.26 \\
1924.45 \\
(259.49-7690.09)\end{array}$ & $\begin{array}{c}24375.05 \pm 36710.25 \\
10047.40 \\
(60-16922.51)\end{array}$ & $\begin{array}{c}26735.27 \pm 36951.36 \\
10863.45 \\
(1217.53-17152.92)\end{array}$ & $\begin{array}{c}19.23 \pm 13.93 \\
15.68 \\
(2.11-62.66)\end{array}$ & $\begin{array}{c}198.60 \pm 299.11 \\
81.87 \\
(9.92-138.45)\end{array}$ & $\begin{array}{c}217.83 \pm 301.07 \\
88.51 \\
(9.92-139.76)\end{array}$ \\
\hline Men & $\begin{array}{c}2127.67 \pm 1740.33 \\
1512.13 \\
(259.49-5708.78)\end{array}$ & $\begin{array}{c}19778.48 \pm 35928.98 \\
8462.79 \\
(325.11-16847.81)\end{array}$ & $\begin{array}{c}21906.14 \pm 35947.00 \\
10163.61 \\
(619.49-17241.83)\end{array}$ & $\begin{array}{c}17.33 \pm 14.18 \\
12.32 \\
(2.11-46.51)\end{array}$ & $\begin{array}{c}161.15 \pm 292.75 \\
82.81 \\
(2.65-137.27)\end{array}$ & $\begin{array}{c}178.49 \pm 292.90 \\
82.81 \\
(5.05-140.49)\end{array}$ \\
\hline
\end{tabular}

All costs are presented as 'mean $\pm \mathrm{SD}$, median and range' 
and local guidelines. ${ }^{11,12}$ By contrast, costs of physical procedures captured only $2 \%$ of total costs. In the population of Sweden, costs due to physical procedures encompass $55 \%$ of total costs, and costs due to medical treatments $7.6 \% .{ }^{24}$ The benefit of physical procedures in treating lumbar pain is well established in the evidence based literature, but these procedures in our survey are mostly performed in private medical facilities and depend on the economic status of patients. ${ }^{28}$ For these reasons, our results differ from the findings of the systematic review of low back pain cost of illness studies by Dagenais $S$ et al, where costs of physical procedures were presented as the largest portion of direct costs. ${ }^{29}$ The lower usage of physical procedures in treating lumbar pain observed in our survey can be explained by the negative correlation between compliance of patients and using adequate health care services, if they are financed only from a patients' perspective. ${ }^{30}$ The domain of indirect costs dominated in the structure of total costs of treating lumbar pain in our study and in studies from other regions. ${ }^{23,29,31}$ Total indirect costs in our study were tenfold higher than total direct costs of treating lumbar pain, which is similar to the finding of a study of van Tulder MW et al, where total direct costs of treating back pain in Netherlands were represented only with $7 \%$. The greater impact of indirect costs in total costs of treating lumbar pain has been anticipated due to the chronic and progressive clinical course of lumbar pain and decreased working ability of these patients, since lumbar pain is etiologically frequently correlated with professional causes. Sick leave due to lumbar syndrome is a frequent problem, whose length varies from 30 to 140 weeks for working time horizon of 40 years, which generates increase in the volume of indirect costs for this medical condition. ${ }^{29,31,32}$ Costs due to productivity losses contribute mostly to indirect costs $(50 \%)$ and they are estimated to be $€ 99.04$, which is lower than in Sweden. These findings in relation to the impact of costs due to productivity losses are similar to those seen in a study by Dagenais $S$ et al. ${ }^{29}$ Since patients with lumbar pain frequently seek out self -medication, we can presume that involvement of this portion of costs was higher than our results showed, which indicates that lumbar pain carries significant medical and pharmacoeconomic burden.

Our survey has certain limitations since we included the calculated sample size and not all the population with lumbar pain, and the data were collected by interviewing patients. This can be explained by the lack of a comprehen- sive patient register and by the fact that certain procedures used in treating lumbar syndrome are mostly carried out in private medical facilities. Intangible costs, which are costs due to pain, changes in social sphere and lifestyle, psychosocial suffering of patients or their families, could not be measured with this questionnaire. Moreover, information about concomitant diseases was not part of our questionnaire and for that reason it could not be evaluated.

\section{CONCLUSION}

Chronic diseases with acute or chronic pain and disability are a significant burden for healthcare and social care systems and patients, due to the major role of indirect costs in the total costs of these diseases. Since these diseases are more prevalent in the older population, we can expect that the total costs of treating lumbar pain would have a greater economic impact, especially in countries with a recent history of social and economic transition. This kind of pharmacoeconomic study, especially from the societal perspective, could provide new information that can guide decision makers in systems with limited resources allocated to health care and with the need for efficient and rational use of the existing resources.

\section{PROTECTION OF HUMANS AND ANIMALS:}

The authors declare that the procedures were followed according to the regulations established by the the Helsinki Declaration of the World Medical Association. This study was approved by the Ethics Committee of Primary Health Institution in Kragujevac (Number of approval 01 - 5099/3).

\section{DATA CONFIDENTIALITY:}

The authors declare having followed the protocols in use at their working center regarding patients' data publication.

\section{CONFLICTS OF INTEREST:}

The authors Matija J. Radoičić, Bojana Božović, Katarina D. Parezanović Ilić, Slobodan M. Janković, Jelena Anđelković and Marina J. Kostić report no conflict of interest in regard to this article.

\section{FUNDING SOURCES:}

This study was partially funded by the grant No 175007 from the Serbian Ministry of Education, Science and Technological Development

\section{REFERENCES}

1. Bhangle S, Sapru S, Panusch R. Back pain made simple: an approach bassed on principles and evidence. Clivlend Clin J Med. 2009;76:393-9.

2. Rives PA, Douglas AB. Evaluation and treatment of low back pain in family practice. J Am Board Fam Pract. 2004;17:23-31.

3. Katz JN. Lumbar disc disorders and low-back pain: socioeconomic factors and consequences. J Bone Joint Surg Am. 2006;88:21-4.

4. Hofreuter K, Koch U, Morfeld M. Social inequality as a predictor of occupational reintegration of chronic back pain patient following medical rehabilitation. Gesundheitswesen. 2008;70:145-53.

5. Denninger TR, Cook Ce, Chapman CG, McHenry T, Thigpen CA. The

influence of patient choice of first provider on costs and outcomes: analysis from a physical therapy patient registry. J Orthop Sport Phys Ther. 2017;26:1-26.

6. Wong AY, Parent EC, Funabashi M, Stanton TR, Kawchuk GN. Do various baseline characteristics of transversus abdominis and lumbar multifidus predict clinical outcomes in nonspecific low back pain? A systematic review. Pain. 2013;154:2589-602.

7. Hoy D, Brooks P, Blyth F, Buchbinder R. The epidemiology of low back pain. Best Pract Res Clin Rheumatol. 2010;24:769-81.

8. Deyo RA, Cherkin D, Conrad D, Volinn E. Cost, controversy, crisis: 
low back pain and the health of the public. Annu Rev Public Health. 1991;12:141-56.

9. Rhee JM, Schaufele M, Abdu WA. Radiculopathy and the herniated lumbar disc. Controversies regarding pathophysiology and management. J Bone Joint Surg Am. 2006;88:2070-80.

10. Kostić M, Jovanović S, Tomović M, Milenković MP, Janković SM. Costeffectiveness analysis of tocilizumab and metotrexate for the treatment of rheumatoid arthritis: a Markov model based on data from Serbia, country in socioeconomic transition. Vojnosanit Pregl. 2014;71:144-8.

11. Grazio S, Vlak T, Gnjidić Z. Uloga neopioidnih analgetika, nesteroidnih antireumatika i slabih opioida u liječenju križobolje. Reumatizam. 2006;53:82-90

12. Ministry of Health of Sarajevo Canton. The Guidelines for Prevention and Treatment of Lumbar Syndrome. 2009. [accessed 2016 May 20]. Available from: https://mz.ks.gov.ba/sites/mz.ks.gov.ba/files/ Lumbalni\%20bolni\%20sindrom2.pdf.

13. Harte AA, Baxter GD, Gracey JH. The efficacy of traction for back pain: a systematic review of randomized controlled trials. Arch Phys Med Rehabil. 2003;84:1542-53.

14. Hayden JA, van Tulder MW, Tomlinson G. Systematic review: strategies for using exercise therapy to improve outcomes in chronic low back pain. Ann Intern Med. 2005;142:776-85.

15. Jo C. Cost-of-illness studies: concepts, scopes, and methods. Clin Mo Hepatol. 2014;20:327-37.

16. Tarricone R. Cost-of-illness analysis. What room in health economics? Health Policy. 2006;77:51-63.

17. Janković S. The Dizajn istraživanja. Kragujevac: Medrat; 2016.

18. Johnsen LG, Hellum C, Storheim K, Nygaard ØP, Brox JI, Rossvoll I, et al. Cost-effectiveness of total disc replacement versus multidisciplinary rehabilitation in patients with chronic low back pain: a Norwegian multicenter RCT. Spine. 2014;39:23-32.

19. Tariff Book of Health Care Services in Health Facilities of Republic of Serbia. Belgrade: Republic Institute for Health Insurance; 2014.

20. The Prices of Medication in Serbia, from december/2014. Official Gazette of Republic of Serbia 133/2014.
21. Pension and disability insurance fund, Republic of Serbia. The cash benefits. 2017. [accessed 2017 Nov 21]. Available from: http://www.pio. rs/lat/novcane-naknade.html.

22. Trading economics. Indicators. 2018. [accessed: 2018 Aug 8]. Available from: https://tradingeconomics.com/countries.

23. Wieser $S$, Horisberger $B$, Schmidhauser $S$, Eisenring $C$, Brügger $U$, Ruckstuhl A, et al. Cost of low back pain in Switzerland in 2005. Eur J Health Econ. 2011;12:455-67.

24. Ekman M, Johnell O, Lidgren L. The economic cost of low back pain in Sweden in 2001. Acta Orthop. 2005;76:275-84.

25. Montgomery $W$, Sato $M$, Nagasaka $Y$, Vietri J. The economic and humanistic costs of chronic lower back pain in Japan. Clinicoecon Outcomes Res. 2017;9:361-71.

26. Luiz Carregaro R, da Silva EN, van Tulder M. Direct healthcare costs of spinal disorders in Brazil. Int J Public Health. 2018.

27. Amaro JL, Moriera EC, De Oliviera Orsi Gamiero M. Pelvic floor muscle evaluation in incontinent patients. Int Urogynecol J Pelvic Floor Dysfunct. 2005;16:352-54.

28. Institute for Quality and Efficiency in Health Care. Systematic Guideline Search and Appraisal, as Well as Extraction of Relevant Recommendations, for a DMP "Chronic Back Pain". 201. [accessed 2017 Nov 18 ]. Available from: http://www.ncbi.nlm.nih.gov/books/ NBK458457/.

29. Dagenais S, Caro J, Haldeman S. A systematic review of low back pain cost of illness studies in the United States and internationally. Spine J. 2008;8:8-20.

30. Giuffrida A, Torgerson DJ. Should we pay the patient? Review of financial incentives to enhance patient compliance. BMJ. 1997;315:7037.

31. van Tulder MW, Koes BW, Bouter LM. A cost-of-illness study of back pain in The Netherlands. Pain. 1995;62:233-40.

32. Burdorf A, Jansen JP. Predicting the long term course of low back pain and its consequences for sickness absence and associated work disability. Occup Environ Med. 2006;63:522-9. 